\title{
LISTENING TO LAW
}

\section{Robert YELḰÁTFE Clifford*}

My journey to better understand and to live my own WSÁNEĆ legal tradition has always been both complex and incredibly rewarding. This journey has, at times, also come with its challenges and tensions, including through law school and academia. Through the use of story I reflect upon this path of learning, and many of my own thoughts and experiences along the way. I have learned, and continue to learn, from many different people along this path, and I am so grateful to each of them. While this story is primarily a selfreflection, the themes and tensions that the character of this story (Cedar) embodies may resonant with many Indigenous people. These themes include family, community, place, identity, stories, law and culture. Each of these themes comes together and to life in this story through lived experience and my own empowering moments of living and coming to better understand WSÁNEĆ law. Ultimately, writing this story helped me in a moment when I needed it. My hope is that you too can find something helpful and rewarding within this story, and that you can use that along your own path.

Le périple que j'ai fait pour mieux comprendre et vivre ma propre tradition juridique dans la communauté WSÁNEĆ a toujours été à la fois complexe et incroyablement enrichissant. Bien entendu, cette expérience a également donné lieu à des défis et des tensions, notamment à l'école de droit et dans le milieu universitaire. À l'aide d'un récit, je décris mon cheminement et bon nombre de mes propres réflexions et expériences connexes. Tout au long de mon parcours, j'ai appris et je continue d'apprendre auprès de nombreuses personnes différentes et je leur en suis infiniment reconnaissant. Bien que ce récit soit d'abord et avant tout une autoréflexion, il se pourrait que de nombreux Autochtones retrouvent une part d'eux-mêmes dans les thèmes abordés et les tensions vécues par le personnage central (Cedar). Qu'il s'agisse de la famille, de la communauté, du lieu, de l'identité, du droit ou de la culture, j'aborde chacun de ces thèmes en décrivant des expériences réelles et le cheminement qui m'a permis de mieux comprendre la loi WSÁNEĆ. En définitive, l'écriture de ce récit s'est révélée une expérience positive pour moi à un moment où j'avais besoin d'aide. J'espère que vous trouverez à votre tour des éléments utiles et éclairants dans ce récit et que vous pourrez vous en inspirer au cours de votre propre cheminement.

JD and LL.M. (University of Victoria), Joseph-Armand Bombardier Social Sciences and Humanities Research Council Scholar and PhD student at Osgoode Hall Law School, York University. I am WSÁNEĆ (Saanich) from the Tsawout First Nation. The Tsawout First Nation is one of four bands that comprise the $\underline{W} S A ́ N E C ́$ Nation. I received the name YELḰÁTłE from my late maternal grandfather, Dr Earl Claxton, Sr. I would like to thank two anonymous reviewers for their comments on an earlier version of this article. I would also like to thank the many people who have supported me throughout both my academic and personal life. I would like to thank in particular my family and my wife Susannah. 
I have never forgotten the words that my father spoke to me one day when we were fishing here. He said that the river is a living thing and if you listen, he will speak to you. ${ }^{1}$

It was almost four years ago, Cedar thought to himself. ${ }^{2}$ Time goes fast. Goes ... But where does it go? 2011, 2012, 2013, 2014 ... Time itself has always fascinated and confused him. Even from a young age, it seemed rather fabricated. A sequence that ticks away in one direction. It's almost depressing if you really think about it. Maybe it was just him. Seasons and land ... It seemed to Cedar there was something a little more concrete to those. The late Lakota scholar Vine Deloria, Jr, had written on this. ${ }^{3}$ Temporal thinking versus spatial thinking. The importance of place and land in an ontological sense. ${ }^{4}$ The discussion was rather philosophical, but there was something to it. It was in God Is Red: A Native View of Religion. ${ }^{5}$ The title had caught Cedar's eye right away. Perhaps he should take another look at that. But here he is, already on a tangent and the story hasn't even started yet. Stories tend to do that somehow. They don't always follow the path you might think they should. ${ }^{6}$ But, of course, that depends on what you bring to a

1 My grandfather, Dr Earl Claxton, Sr, spoke these words while telling the story of The Living River. Arthur Holbrook Productions recorded the story for the production of a video for the British Columbia Heritage Rivers Board. The passage provided here is quoted in Rachelle Clifford, My Grandfather the Cedar, My Grandmother the Wool (Masters in Applied Arts in Design thesis, Emily Carr University of Art and Design, 2010) [unpublished].

2 Originally I wrote this story without any footnotes. In some ways, the story seemed to serve its purpose better without footnotes because it remained more fluid and open to interpretation. While I have since added a number of footnotes, they are not meant to narrow the range of interpretation or the potential of layered meaning throughout. Nor are they meant to necessarily provide any type of definitive or authoritative weight to a given insight. Rather, they are meant to provide additional information and a few potential sources or examples with which the reader might follow up on a given point. In other words, I hope they open possibilities as opposed to restrict them. I also questioned whether to write this story in the first or third person. The reason for my uncertainty is that on one level Cedar reflects my own personal experiences and insights. However, on another level, Cedar embodies and engages with issues not limited to any given individual. Cedar is therefore also multi-layered and open, like all stories, for the reader to inhabit or reflect upon as they go. For instance, the name itself, Cedar, might be seen as reflecting the cedar tree and its cultural, spiritual, and ceremonial significance for WSÁNEĆ and other west coast Indigenous groups and, in that sense, also invite symbolic connections with strength and revitalization.

3 See Vine Deloria, Jr, God Is Red: A Native View of Religion, 30th anniversary ed (Golden, BC: Fulcrum Publishing, 2003).

4 Place, and the importance of place in Indigenous law and WSÁNEĆ teachings, is a theme that comes up in various ways throughout this article. See ibid for more. See also Janet Poth, ed, Saltwater People: As Told by Dave Elliot Sr, 2nd ed (Saanich, BC: Native Education School District 63, 1990); Philip Kevin Paul, The Care-Takers: The Re-emergence of the Saanich Indian Map (Sidney, BC: Institute of Ocean Sciences, Department of Fisheries and Oceans, 1995) for more on the importance of place-names and their connection to WSÁNEĆ creation stories.

5 Deloria, supra note 3.

6 There is an important difference in pedagogy involved here; one that is much less linear than some readers may be accustomed to. 
story and what you think a story ought to do. ${ }^{7}$ And it is never just one story. ${ }^{8}$ That makes it hard. To explain one thing, you usually need to explain another first. But where does that get us? Are we always forced to try and explain something else? Could you even explain it all if you tried? Theoretically, perhaps; but daily life doesn't often unfold at that level of awareness. So where would we be? Stuck? No, that won't work either. You pick a point that seems to fit and you jump in. You do your best. That's the only way to tell a story. Sometimes Cedar forgets this. But this is quickly followed by gratefulness, because he always has people there to remind him. But back to things ...

It was almost four years ago ...

No, that won't work either. The story has to start earlier than that. Cedar contemplates. He can't recall the date, but he knows where he was and that he was with his family. ${ }^{9}$ He gains confidence in knowing where the story should start. It was on the Tsawout Reserve. ${ }^{10}$ They were all in his grandmother's backyard. That place held so many memories for him. He couldn't count the hours he spent there with his cousins playing and running around. His grandfather was there too. They were going to have a burning ceremony. That was the first burning ceremony he had been to, Cedar remembers. He was not that old, but old enough to be tasked with helping his grandfather with the ceremony; at least the simpler parts. He helped stack a low table with salmon, fish soup, tobacco, and other assorted food and drinks. Under the table were logs, kindling, and paper. The structure was lit on fire, and as it burned his grandfather conducted the ceremony. Cedar didn't know much about burning ceremonies back then. His grandfather had said they were going to honour and provide food and nourishment to their ancestors. The food prepared and being offered were some of the ancestors' favourites while they were alive.

Leading up to the ceremony Cedar's family had explained there had been signs that it was time to do this. Cedar hadn't seen them or even really known what he could have been looking for. But the general sense and understanding he got was that something wasn't in balance; that our ancestors needed our attention. That was the first time he really learned that as WSÁNEĆ people we have responsibilities to

7 Indigenous research methodologies often remind us of the importance of reflexivity. Our relationship to a story and what we learn from that story may also often change over time. For more on Indigenous methodologies, see generally Margaret Kovach, Indigenous Methodologies: Characteristics, Conversations, and Contexts (Toronto: University of Toronto Press, 2009); Linda Tuhiwai Smith, Decolonizing Methodologies: Research and Indigenous Peoples, 2nd ed (London: Zed Books, 2012); Shawn Wilson, Research Is Ceremony: Indigenous Research Methods (Halifax: Fernwood Publishing, 2008). Readers may also see generally Jo-ann Archibald (Q'um Q'um Xiiem), Indigenous Storywork: Educating the Heart, Mind, Body, and Spirit (Vancouver: UBC Press, 2008) for an approach to understanding stories in Indigenous knowledge systems.

8 Applying this insight specifically to the study of Indigenous law, I find it useful to draw upon the work of John Borrows when he identifies that Indigenous legal orders "cannot be understood without an appreciation of how each story correlates with others. A full understanding of [Indigenous] law requires familiarity with the myriad of stories of a particular culture and the surrounding interpretations given to them by their people." John Borrows, Recovering Canada: The Resurgence of Indigenous Law (Toronto: University of Toronto Press, 2002) at 16 [Borrows, Recovering Canada].

9 Throughout this article, there are opportunities to reflect upon the notion of "place" and its relationship with experiential learning and embodied practice as well as how this practice differs from abstract reasoning and theorizing.

10 The Tsawout First Nation reserve is also known as the East Saanich Indian Reserve no 2 and is located on the east side of the Saanich Peninsula, north of Victoria, British Columbia. 
our ancestors, as well as ways of tending to those responsibilities. ${ }^{11}$ This teaching was central to $\underline{\text { WSÁNEĆ }}$ beliefs and something his grandfather had told him at various times and in various ways, though not often explicitly. In fact, while it was central to learning about the burning ceremony, it was also the principal theme of the final story his grandfather shared with him; a story about LEL,TOS. ${ }^{12}$

Cedar was in his final year of law school. ${ }^{13}$ He had gone to law school to learn and eventually practice Aboriginal law. ${ }^{14}$ He had wanted to help First Nations communities assert their rights. Aboriginal law seemed to be the best way to do that. He even started working at an Aboriginal law firm in Victoria during law school. Everything seemed on track. But something didn't fit quite right. ${ }^{15}$ It was hard to see the many ways Canadian law failed Aboriginal people. But that wasn't it; at least, not all of it. It was something different. Something more. Maybe it could be explained in terms of power dynamics, or discourse theory, or some equivalent. It was complicated. But, basically, there seemed to be a disconnect. He could feel it, and it lingered with him for many years. ${ }^{16}$ At the time, Cedar had been learning about Indigenous law and how the legal traditions of Indigenous peoples might hold a much more productive answer to the endless tensions and barriers that arise in Aboriginal law. ${ }^{17}$ That path wasn't any less complicated. But it felt true.

11 The WSÁNEĆ are an Indigenous Nation comprised of what are now four First Nations bands created under the Indian Act, RSC 1985, c I-5: Tsawout, Tsartlip, Tsycum, and Pauquachin.

12 ŁEL,TOS is an island within WSÁNEĆ territory. ŁEL,TOS is the SENĆOFEN name for James Island. SENĆOFEN is the language of the WSÁNEĆ people.

13 I went to law school in the Faculty of Law at the University of Victoria in Victoria, British Columbia. I completed my final year of law school in 2011.

14 By Aboriginal law, I mean specifically the branch of Canadian law that relates to Indigenous peoples.

15 For an excellent article exploring the difficulty of law school and legal academia for Indigenous peoples, see Robert Williams, Jr., "Vampires Anonymous and Critical Race Practice" (1997) 95 Michigan L Rev 741. Another excellent book exploring this same theme and more is Patricia Monture-Angus, Thunder in My Soul: A Mohawk Woman Speaks (Halifax: Fernwood Publishing, 1995).

16 I have since read many different works that touch generally, from various perspectives, upon this tension regarding Aboriginal law. I mention but a few here. For a critique of Aboriginal case law and some of the reasoning and assumptions behind it, see John Borrows, "Frozen Rights in Canada: Constitutional Interpretation and the Trickster" (1997) 22:1 Am Indian L Rev 37 [Borrows, "Frozen Rights"]; Lawrence Barsh \& James Youngblood Henderson, “The Supreme Court's Van der Peet Trilogy: Naive Imperialism and Ropes of Sand" (1997) 42 McGill LJ 993. For more on the notion of sovereignty and its web of meaning and assumptions, see Gordon Christie, "Indigeneity and Sovereignty in Canada's Far North: The Arctic and Inuit Sovereignty” (2011) 110:2 South Atlantic Quarterly 329. For a critical analysis of the Aboriginal law paradigm, see Patricia Monture-Angus, Journeying Forward: Dreaming First Nations' Independence (Halifax: Fernwood Publishing, 1999). Finally, for a stronger critique of Aboriginal law as a continuation of imperialism, see Glen Coulthard, Red Skin, White Masks: Rejecting the Colonial Politics of Recognition (Minneapolis: University of Minnesota Press, 2014); Taiaiake Alfred, Wasáse: Indigenous Pathways of Action and Freedom (Toronto: University of Toronto Press, 2009).

17 The work and guidance of John Borrows was hugely important in this regard. See generally Borrows, Recovering Canada, supra note 8, John Borrows, Canada's Indigenous Constitution (Toronto: University of Toronto Press, 2010) [Borrows, Indigenous Constitution]; John Borrows (Kegedonce), Drawing Out Law: A Spirit's Guide (Toronto: University of Toronto Press, 2010). 
Cedar's grandfather lay in bed. He had been sick and spent most of his time there these days. On this day, Cedar had come to visit and to ask about LEL,TOS. You could see the island from the window of his grandfather's room. Most people called it James Island these days. Actually, that is how Cedar first knew it. He had spent a great deal of time there; at least on the ocean around the island and on the beach. Never further. Never past the high water mark. The island was named after Sir James Douglas, Governor of Vancouver Island. Douglas had concluded a number of treaties in the area, including with the WSSÁNEĆ in $1852 .{ }^{18}$ Cedar preferred the name LEL,TOS.

$Ł E L, T O S$ is not a large island, but it has many stories to tell. It was a temporary village site, harvesting location, and the site of a burial ground for the WSÁNEĆ people prior to the Douglas Treaty. Soon after the Treaty, it had many other stories to tell as well. It was purchased and farmed by a Scottish family, it was stocked with deer and established as a private hunting reserve for the elite, it was the location of the largest munitions powder manufacturer in Canada during the war years, and it was a significant settlement location during that time. As time passed, the dynamite factory continued to operate, the land was contaminated and used as a toxic dumpsite, and portions of the island were logged. After that, in the 1980s, the island was sold and set to become a world-class golf resort and development that would attract people from around the globe. The most renowned course designer was brought in to make this happen. The course was built; you could see it from the ocean when fishing. But the cost of rehabilitating the island proved too much, and the island was again sold. This time it was bought by a billionaire who environmentally rehabilitated the contaminated island with the vision of creating an "eco-paradise" where wealthy individuals could dock their yachts and find a private and secluded retreat in nature. Bill Gates was perhaps one of the most famous visitors of the island. The "eco-paradise" only partially came to fruition, but the island remains in private (and secluded) ownership. ${ }^{19}$

These stories hurt. But what Cedar wanted to learn from his grandfather was more about the context in which we as WSSÁNEĆ people understand these stories. He wanted to know the stories that told us how to interpret these harmful events. How we understand our relationship with ŁEL,TOS. How could he say anything about WSÁNEĆ law on this land without that? Cedar grasped at the thought, and it began to build. That is the key difference he thinks. It is not just considering a different set of laws or rules. It is a

18 Two separate treaties were made with the WSÁNEĆ - The Saanich Tribe (North Saanich) and the Saanich Tribe (South Saanich). Each treaty covers different areas of land, though are otherwise very similar in content. For further details, see Aboriginal Affairs and Northern Development Canada, "Treaty Texts - Douglas Treaties," <http://www.aadncaandc.gc.ca/eng/1100100029052/1100100029053>. For further background and information in relation to the Treaty, see also Tsawout First Nation, "The Douglas Treaty," <http://www.tsawout.com/department/douglas-treaty-elders-workinggroup/treaty-information/the-douglas-treaty>.

19 A general account of the settler history of James Island, which includes several of the abovementioned events, can be found in Bea Bond, Looking Back on James Island (Sidney: Porthole Press, 1991). For more on the golf course development, see, for example, Girard Hengen, "Golden Bear Makes the Rounds on James Island Course," The Review (13 November 1991) A25, Vertical File Subject: James Island, Sidney Archives. For more on the "eco-paradise," see, for example, Andrew Findlay, "Craig McCaw's Treasure Island,” BC Business Online (2 December 2009). 
shift in our thinking and approach, more than anything else. ${ }^{20}$ We build from there. The matter remained complicated in Cedar's mind, but he had something to grab on to. The path would be hard, uncertain, and contested - both from within and outside. But he felt sure that his grandfather's story of ŁEL, TOS could be the path he followed in the darkness of this uncertainty. ${ }^{21}$ Cedar hoped only for that.

A long time ago, when the Creator, XÁLS, walked the Earth, there were no islands in the $\underline{W}$ SANEĆ territory. The islands that are there today were human beings (our ancestors). At this time, XÁLS walked among the WSÁNEĆ People, showing them the proper way to live. In doing this, he took a bunch of the WSÁNEĆ People and threw them out into the ocean. Each of the persons thrown into the ocean became the islands there today. Each of those islands were given a particular name that reflects the manner in which they landed, their characteristics or appearance, or the significance they have to the WSÁNEĆ People. "James Island" was named ŁEL,TOS, meaning "Splashed on the Face." $E E L, T O S$ reflects the way the island landed in the ocean. The southeast face of $€ E L, T O S$ is worn by the wind and the tide.

After throwing the WSÁNEĆ People into the ocean, XÁLS turned to speak to the islands and said: "Look after your relatives, the WSÁNEĆ People." XÁLS then turned to the WSÁNEĆ People and said: "You will also look after your 'Relatives of the Deep.", This is what XALS asked of us in return for the care our "Relatives of the Deep" provide for us.

In thinking back on the story his grandfather had told him, Cedar reflected on the SENĆOFEN word for "island" - TETÁĆES. His uncle had told him of this word. Of course, using the word "uncle" or "cousin" in the community doesn't always have the same fixed meaning as elsewhere. It was a relation he spoke with, but not an "uncle" in the typical sense. It was someone he respected and knew he could learn a great deal from. His uncle had told him that TETÁĆES was a conjunct of two other words in SENĆOFEN: TEĆ (meaning deep) and SĆÁLEĆE (meaning relative or friend). He told Cedar this was because islands

20 I have argued this point in greater detail in relation to a fuel spill in WSSÁNEĆ territory. See Robert YELḰÁTfE Clifford, "WWSÁNEĆ Legal Theory and the Fuel Spill at SELEKTEE-(Goldstream River)" (2016) 61:4 McGill LJ 755. This article is a revised version of my LLM thesis in the Faculty of Law at the University of Victoria.

21 Although I refer to this here as my grandfather's story, that is only to recognize him as one of the people from whom I learned the story. I have heard others tell this story as well, and it is not owned by anyone. It is important to recognize the diversity of stories, and I do not presume to state the definitive account of this or any other story. I also note that I have found the work of Johnny Mack persuasive on this point. Mack states: "My sense is that, by looking to our own stories and attending to the health of our connection to them, we would become a more grounded, healthier peoples, better equipped to identify, withstand, and/or subvert the imperial impetus of treaty processes as well as imagine more balanced modes of reconciliation that respect [Indigenous] stories." See Johnny Mack, "Hoquotist: Reorienting through Storied Practice" in Hester Lessard, Rebecca Johnson \& Jeremy Webber, eds, Storied Communities: Narratives of Contact and Arrival in Constituting Political Community (Vancouver: UBC Press, 2011) 287 at 293. 
were our "Relatives of the Deep," and he connected the word to the creation story of TETÁĆES. ${ }^{22}$ Another thought came to Cedar that he grasped onto. Language is central too. There is so much in language that helps you understand these stories - the values, philosophies, and everything that gives substance and body to these stories. ${ }^{23}$ He needed to understand these stories to know about WSÁNEĆ law, but there is so much between the lines and underlying these stories that he also needed to learn. ${ }^{24}$ If not, he felt his understanding would only be superficial. He felt he needed to dig even deeper.

This was another important epiphany, Cedar thought. He had added an important layer. Or was it that he peeled back a layer? It depends on how you think of it, he supposed. Regardless, if he could understand what made these stories work then that would be a key to really understanding WSÁNEĆ law. Of course, this is complicated because it is at a level of abstraction that we don't often think about. How would you even describe this? That alone was hard enough. He knew there was something there he wanted to describe or make clear to others, but he couldn't figure out exactly how to go about it. Since he was at university, his solution at the time was to read more books. Some of these books seemed rather foreign or abstract to Cedar, and many times they didn't match up with how Cedar saw or experienced things. Nonetheless, he tried to take from them what was useful. Over the years, Cedar used concepts such as "epistemology," "ontology," and "cosmology" as potentially helpful. ${ }^{25}$ It was a fancy way of thinking about the nature of knowledge and being at both the physical and metaphysical level. Really, for Cedar, it was about relationships and how we understand them. Relationships are important because law is really about how we understand and tend to those relationships. But Cedar catches himself. A story can't move too fast or else it gets somewhere before it's time.

Besides, if he thought too much in this way, his head started to spin. Just when he thought he had grasped something useful, he could just as easily get overwhelmed and uncertain. At those times, he would think he only saw the tip of the iceberg. He would think of how much you must have to know in order to fully understand WSÁNEĆ law. Land, language, stories, ceremony ... It's a lifelong journey. What made him think he could say anything about WSÁNEĆ law so early in his journey? Besides, it is not just WSÁNEĆ law he would have to know but also to be able to explain and defend it (because he would have to defend it to those who didn't understand) in a completely different way as well. Epistemology, ontology,

22 I would like to thank John Elliott for the several conversations we have had on this topic and for helping me to understand more about our "Relatives of the Deep."

23 I do not take a fundamentalist stance on language, but I see the revitalization of Indigenous language as an important aspect of Indigenous resurgence and Indigenous law. I find the approach used here to break down the word TETÁĆES into smaller words that reveal a deeper meaning to be very useful, particularly for non-fluent speakers. See Leanne Simpson, Dancing on Our Turtle's Back: Stories of Nishnaabeg Re-creation, Resurgence and a New Emergence (Winnipeg: Arbeiter Ring Publishing, 2011) at 49 for more on this same approach. For more on the SENĆOFEN language and its centrality in WSÁNEĆ teachings, in particular, see Paul, supra note 4.

24 Julie Cruikshank, Do Glaciers Listen? Local Knowledge, Colonial Encounters, and Social Imagination (Vancouver: UBC Press, 2005) at 66 notes: "Storytelling may be a universal human activity, but understanding what one hears requires close attention to local metaphor and local narrative conventions. When speaking in story-like constructions, Yukon elders tend to make generous assumptions about their listeners' or readers' understandings of such precepts. ... It is, of course, precisely the absence of such knowledge that often makes cross-cultural communications so fraught."

25 Typically, we see these terms as branches of Western philosophy. However, the work of Christine Black was influential in helping me bridge the gap and to more fully explore the connection between Indigenous cosmology and Indigenous law. See Christine F Black, The Land Is the Source of the Law: A Dialogic Encounter with Indigenous Jurisprudence (New York: Rutledge, 2011). 
cosmology... And what about all the tensions that can arise? Capitalism, liberalism, neo-liberalism.... How do we even think about addressing these tensions? Recognition theory, resurgence theory, selfdetermination, deep legal pluralism.... Not to mention power dynamics? Discourse theory, postcolonial theory... In order to understand these theories, it seemed that there was a maze of books to be lost in.

Theory is helpful, Cedar thought. It can help you uncover insights that previously went unnoticed. There is something valuable to it, and he was on to something important, he didn't doubt. But sometimes theorizing only gets you so far. It is too easy to get stuck inside your head. It tends to get complicated, and if you're not careful you can end up where you didn't intend to go. It can be hard to remember this. For Cedar, it was usually a lived experience that helped him keep his feet on the ground. That reminds him, where was he going with this again? Oh, yes ...

It was almost four years ago ...

It was June, sunny, and beautiful. The type of day in which you just feel good. At least that is how he remembers it. Cedar had a PLTC [professional legal training course] ${ }^{26}$ at Camosun College that day. ${ }^{27}$ Normally, that is the last thing he would want to be doing on a day like this. But that didn't seem to bother him that day. In his class, he had been learning about builder's liens. ${ }^{28}$ It was somewhat complicated, and he suspected he would never represent someone wanting to file a builder's lien. But he was told he needed to know it to pass the PLTC and get called to the Bar. It became more interesting to him when he thought of it in terms of relationships, which at its broadest is what it was all about he thought - the relationship between the contractor, the materials supplier, the landowner, and even the land itself. In this light, the common law, like Indigenous law, is also about relationships, Cedar thinks. Just in a very different way; and the relationships envisioned are themselves very different. So too is the agency given to different parties. Of course, they are never static or one dimensional, but what had been troubling to Cedar about the common law and all that drives it (or is driven by it) was the lack of agency commonly given to the world in which humans were situated, and the hierarchical nature of many of the relationships. ${ }^{29}$ There $^{2}$ were many examples, but even something as simple as a builder's lien would give you insights into this if you took the time to really think about it. Something Cedar also could not understand is why learning and tending to these relationships through stare decisis, legislation, or so on was any more legitimate than through WSÁNEĆ stories and the land. It could all be rather frustrating to think about for him.

Luckily, it was lunch break and time for Cedar to get outside to enjoy the sun and have a break from the classroom and from builder's liens. He usually liked to spend lunch alone. He needed time to unwind,

26 The professional legal training course is part of the Law Society of British Columbia's bar admissions program and is required to become a lawyer in British Columbia.

27 Camosun College is a post-secondary institution located in Victoria, British Columbia.

28 In simplified terms, a builder's lien is used to help secure payment for material or work provided on a construction project by registering a charge against the title to the land or property on which the work was undertaken.

29 A particularly striking difference rests in the different agency given to land and the non-human world. I have begun to explore this elsewhere in relation to a fuel spill at Goldstream River near Victoria, British Columbia. See Clifford, supra note 20 . 
and classmates usually just wanted to talk more about law. Besides, Camosun has a beautiful little campus; right outside the building, there is a nice quiet field lined with trees, rocks, and bushes. It was a perfect place to sit, relax, and to feel the peace of the land. As Cedar sat there, his mind turned again to his grandfather - YELḰÁTFE. Cedar worried about him. His grandfather had been sick for a number of years by that time. He was not doing well. This realization made Cedar think - to think about things that are hard to understand. His grandfather was an inspiration to him, and Cedar was honoured to carry his name, YELḰÁTFE. Names are important.

Cedar thought not just about his grandfather but also about his late great-grandmother as well. He even thought about many of his other relatives. Some of them, he had never even known. That didn't diminish their importance, especially at that moment. He knew that his grandfather was going to join them. Cedar didn't claim to have all the answers or to understand it all. Actually, he worried about it all a great deal. As he sat there, consumed with these thoughts, he looked over next to him. "My friend the SMÍEF," Cedar said aloud. His grandfather had always said that when he saw a deer (SMÍEF). That was Cedar's first thought as he saw a deer lying down in the brush no more than ten to fifteen feet away from him. It was a surreal experience. Deer tend to be skittish for the most part. They won't usually let you get that close to them, especially if they are lying down. Had it been there this whole time? It was an unusual experience, but it didn't seem strange. In fact, it actually felt exactly right given the thoughts in his mind.

Cedar had been worrying. He worried about his grandfather, of course. But also about what the loss of his grandfather would mean for himself, his family, and the community. Would they all be okay? Would his grandfather be okay? It had been hard. It would get harder, he had been thinking. But all of this seemed to drift to the background sitting with SMÍEF. It was peaceful. Cedar sat there with the deer for the remainder of his break. He listened. Not just with his ears, or his mind, but with his heart too. ${ }^{30}$ It was more a feeling than anything else. Such a moment is hard to explain. It was a moment between himself, the deer, his grandfather, and the relatives that had been on his mind. A connection. It was the big picture for Cedar. A sense of being in this world and on this land, and all that meant. SMÍEF, his grandfather, and his ancestors had come to him at a time when Cedar needed them. When he had felt lost, scared, and uncertain. Cedar felt clarity in this moment. He knew that while his grandfather had fought long and hard, that his passing was close. But with that realization he also knew that, although the loss of his grandfather would be hard, that there was so much he would still teach Cedar, and that he would always be there when Cedar needed him. All he had to do was listen.

Cedar's grandfather passed away no more than a few days later, in the very early morning of the day of Cedar's convocation for law school. His grandmother, who had spent close to every minute with Cedar's grandfather for the many years he was sick, said that his grandfather knew it was the only way that both of them could make it to the ceremony. It was a sad day, but a special day.

Cedar and his family, along with many others from the community, gathered around the cemetery on the shore of the bay at the Tsawout Reserve. His grandfather was to be buried next to his great-grandmother

30 Jo-ann Archibald (Q'um Q'um Xiiem) also writes about listening with your heart in terms of Indigenous storywork. For more, see Archibald, supra note 7. 
and other relatives. The burial had begun. Three eagles came and soared overhead. They circled above during a significant part of the burial. It was powerful and majestic. Cedar understood that in WSÁNEĆ culture ancestors can visit you in the form of animals, particularly larger birds, including eagles. Cedar could not speak for everyone there, but he knew that his immediate family was moved by the presence of the eagles as his grandfather was buried.

Cedar had been called to the Bar and was a practising member of the Law Society of British Columbia. He was the first person from the WSÁNEĆ Nation to become a lawyer. His family was proud. But Cedar's uncertainty lingered. He wasn't sure that the practice of Aboriginal law was his calling. It didn't really match his personality or his passion. His grandfather had devoted his life to saving the SENĆOFEN language and had envisioned and promoted a WSÁNEĆ Nation that drew strength from its culture and language. His efforts had contributed to a SENĆOFEN immersion program at the WSSÁNEĆ tribal school and many other important achievements. His work brought him an honourary Doctor of Laws degree from the University of Victoria and great respect within the WSÁNEĆ community. Dr. YELḰÁTFE, his family would call him sometimes with pride, but also in a way they knew would make everyone smile. Cedar carried that name now. Minus the Dr. part, of course. Having that name mattered to Cedar. In carrying that name he not only felt an obligation, but also a passion, to continue and build upon his grandfather's vision in his own way. Cedar felt more and more certain that the study and revitalization of Indigenous laws was the best way he could do that.

Cedar went on to graduate work. He learned more about Indigenous law, various theoretical approaches, and methodological frameworks. He tried to put it on the ground in a way that mattered to him and his community. He wrote about a fuel spill at a salmon spawning river where he and his community fished. That river meant a lot to him. He received a Master of Laws for his work. ${ }^{31} \mathrm{~A}$ great accomplishment, but there was so much left he wanted to write and think about. There was so much left to learn and understand. He decided to step outside his comfort zone and to start a doctoral degree in Toronto. Cedar had been accepted into a great school and was excited by what he could learn there. He thought it would be hard to learn more about WSÁNEĆ law in Toronto, but he knew he could learn a lot about different ways to think of law and its place in the world. That was exciting to him. He knew it would be valuable. But he also knew it would be a challenge.

Cedar had been studying hard at his new school. He had been thinking a lot about law, culture, philosophy, politics, economics, and the like. It all seemed very interconnected to him in some way or another. If he could just get a grasp on things, he was sure he could explain something worthwhile. It would somehow add another layer to his analysis of Indigenous law. But, to be honest, it was starting to get overwhelming, and he was feeling exhausted. There was so much. Maybe he was letting himself get side-tracked a little.

31 Clifford, supra note 20. 
He needed to rest. He began to slip into sleep as a debate he had been reading about and grappling with for quite some time circled through his mind.

Cedar was back at home in WSÁNEĆ territory standing on the beach and gazing at ŁEL, TOS in the distance. As he stood there, Raven came and perched on the log next to him and they began to talk. ${ }^{32}$ Raven was concerned with Cedar's use of WSÁNEĆ stories and wanted to let him know. "Why are you using WSÁNEĆ stories to talk about law?" asked Raven. Cedar explained that WSÁNEĆ stories and the values and philosophies they held provided a different way of looking at the world; a different way of relating; a different way of understanding the work of law. Cedar explained how he felt that understanding that was central to revitalizing WSÁNEĆ law. ${ }^{33}$ It was a chance to create the space for an alternative narrative and discourse. To be guided by our own stories. ${ }^{34}$

Raven sensed a chance to really test Cedar here. "But whose stories? The "WSSÁNEĆ? I have heard you tell a story about ŁEL,TOS. You do know that not all WSÁNEĆ people even know that story, tell it the same way, or place the importance on it that you seem to, right?" explained Raven. "Are those people wrong? Or, if this story is so central to being WSÁNEĆ, are those people less WSÁNEĆ?" probed Raven. "And what 'values' and 'philosophies' do you speak of, as though they are concrete and identifiable? Everything cannot be contained so neatly," argued Raven. "People take influence from other cultures, other creation stories, and so on. Things are much more fluid than you seem to think, Cedar. I fear that you might be limiting that freedom if you emphasize the centrality of these stories too emphatically," expressed Raven. "It could be oppressive, or at least work to homogenize WSSÁNEĆ culture and identity. Cultural norms, practices and identity need to remain open to deliberation and contestation," Raven explained. "Besides, those stories are old. What use can they really be today? You shouldn't try and return to the past. You should focus on the future," Raven implored. "Culture needs to change. The world is so different today than when those stories were used. There is no sense freezing things in the past. I am just trying to help," asserted Raven. "I have heard others talk about these sorts of things. I think they called it essentialism. You should be careful" implored Raven.

Cedar was somewhat taken aback. He had not heard Raven talk in such a way before, but he supposed it wasn't the first time that Raven had surprised him. Nonetheless, Cedar felt somewhat uncertain, and

32 Raven is a culturally important figure in WSÁNEĆ culture and stories, as well as for other west coast Indigenous groups. Raven can play the role of a trickster and is often unwittingly the founder of a lesson. While Mink may be the more central trickster character in WSÁNEĆ culture, I have chosen the trickster character of Raven here, in part to reach a slightly wider audience.

33 I have found the work of Raymond Austin to be one source that has been helpful in thinking about the role of values and principles in Indigenous law. Austin describes the foundational principles of Navajo law as conditions generated through law, as opposed to basic legal principles to be directly applied. In other words, they are what we strive for. See generally Raymond Austin, Navajo Courts and Navajo Common Law: A Tradition of Tribal Self-Government (Minneapolis: University of Minnesota Press, 2009).

34 I take influence here from the work of Gordon Christie. See Christie, supra note 16. Readers may also find the literature on Indigenous resurgence helpful in this regard. See Alfred, supra note 16; Simpson, supra note 23, for two leading texts on Indigenous resurgence. 
even a bit frustrated. Raven had made some important points but also seemed to misconstrue others. The matter was complex. Cedar tried to begin explaining himself as best he could, though he wasn't sure it would help. Cedar agreed that the dichotomy between "authentic" / "traditional" and "inauthentic" / "contemporary" was problematic. It could work in oppressive ways. Aboriginal law had for far too long been promoting such distinctions. ${ }^{35}$ It would be simplistic to blame only colonialism on such matters, but it certainly fueled this dynamic. It would be equally simplistic to think the dynamic would simply go away with a turn towards Indigenous law and these stories. Internal power dynamics always require attention. ${ }^{36}$ Did Raven think Indigenous law was not capable of dealing with them in its own way? Or did he think that internal power dynamics were not still a major issue in the common law? That the common law did not restrict so called dissident members? Or was it more that he assumed Western liberal democracy had a monopoly on the most just and fair way of dealing with these ever-existing tensions? Cedar wasn't sure, but one level of Raven's critique seemed to imply, or at least not critically reflect upon, these questions.

In hoping to address Raven's concern, Cedar explained that he knew it would be important to not reinforce a dichotomy that placed tension between traditional and contemporary. In fact, by arguing that we could breathe new life into these stories and use them to guide our lives today in dynamic and innovative ways, Cedar felt he was helping to break this dichotomy, not reinforce it. John Borrows, a great teacher and mentor had helped him understand this. ${ }^{37}$ Cedar explained to Raven that he knew culture and identity were dynamic. He didn't think otherwise. In speaking about $Ł E L$, TOS it was not that he imagined all WSÁNEĆ people understood "islands" as their "Relatives of the Deep", or that such an understanding was essential for WSÁNEĆ identity. Some people had this understanding. Some did not. Some did not reflect upon it in any detail. And some understood it in a more metaphoric way. It was also true that some people may potentially emphasize certain interpretations of various stories in an effort to reinforce their own position of power in the community. Any given story didn't hold all the answers. But for Cedar, all of that didn't mean there was not something important to think about in the story.

Cedar recognized that he had elements of cultural preservation and revitalization in his thinking. But Cedar and Raven seemed to see this in a very different light. For Raven, it was misguided and potentially oppressive. For Cedar, it could be an empowering act of resistance and self-determination. Cedar wondered if Raven perhaps considered this debate without enough attention to the history and processes of colonialism. Raven's comments seemed to obscure the operation of power. These claims for cultural revitalization didn't happen in a vacuum. Cedar found support for these thoughts in the recent work of Glen Coulthard.$^{38}$ Indigenous peoples have been subjected to a long history of assimilation policies and attempts at erasing Indigenous culture. It is not surprising that in continuing to resist this pressure Indigenous peoples make claims relating to cultural preservation and revitalization. To cast these claims

35 John Borrows provides an important critique of the test for Aboriginal rights in $R v$ Van der Peet, [1996] 2 SCR 507, that speaks to part of this tension. See Borrows, "Frozen Rights," supra note 16.

36 Emily Snyder has done important work that centers on questions relating to gender in the work of Indigenous law. See generally Emily Snyder, "Indigenous Feminist Legal Theory" (2014) 26 CJWL 365.

37 For a great collection on centering Indigenous stories, see also Jill Doerfler, Niigaanwewidam James Sinclair \& Heidi Kiiwetinepinesiik Stark, Centering Anishinaabeg Studies: Understanding the World through Stories (Winnipeg: University of Manitoba Press, 2013).

38 See Coulthard, supra note 16. 
as restrictive, as if Indigenous culture is somehow a threat to the individual and to foundational principles of Western liberal democracy, is dangerously close to maintaining the logic that Indigenous cultures need to be overcome for their own good. ${ }^{39}$

A primary concern for Raven seemed to be the restriction of agency. Cedar did not see Indigenous law as restricting agency. Actually, he felt as though he was promoting important aspects of agency, not just in the WSÁNEĆ community, but extending that agency back to the non-human world as well. One aspect of this was the agency of resistance he had explained to Raven. That agency tended to seem overshadowed when emphasis was placed only on the essential need for culture and identity to remain open to crosscultural influence. Particularly since it seemed fairly evident that the presumption was that this "crosscultural influence" should function primarily in one direction. There are power dynamics here that cannot be forgotten, Cedar reminded Raven. ${ }^{40}$

Raven also seemed to misconstrue Cedar's emphasis on WSÁNEĆ stories as restricting individual agency in terms of interpretation and choice. Raven seemed to think that there was only one way to interpret or use a story and also that these stories inevitably emphasized a gaze towards the past. For Cedar, both of these assumptions were misconstrued. The notion of returning to the past was particularly frustrating to Cedar. He wondered why Indigenous cultures are always relegated to the past? ${ }^{41}$ Despite this frustration, Cedar tried to explain these two points to Raven as best he could.

For Cedar, WSÁNEĆ stories were not about returning to the past. He explained to Raven that it is about what, for example, the story of TETÁĆES can teach us and about how we choose to use and relate to that story today. Cedar thinks back to his time in law school. He thought perhaps a metaphor Raven would be familiar with could help. Cedar explained that the common law speaks of a "living tree." Certainly, the branches continue to grow. Culture and law are dynamic. But do we forget about the trunk or the roots of the tree in the metaphor $?^{42}$ All legal orders have them and are guided by them, whether they explicitly acknowledge it or not. Cedar explains that he understands the WSÁNEĆ to have always occupied a normative universe that governed how to ask and answer questions of law. This does not negate a dynamic approach to law and culture - that these were ever evolving and changing (some unfortunately through an oppressive assertion of power from the outside). Yet they have never been erased. The reason they remain is that, despite their dynamic nature and attempts to erase them, the WSÁNEĆ have (through

39 Glen Coulthard offers an insightful analysis on many of the issues regarding essentialism discussed here. See Coulthard, supra note 16, particularly ch 3 ("Essentialism and the Gendered Politics of Aboriginal Self-Government") for more.

40 There are many scholars who write about Indigenous resistance. One example is the recent work of Audra Simpson, which has gained significant acknowledgement. See generally Audra Simpson, Mohawk Interruptus (Durham, NC: Duke University Press, 2014).

41 Jean O'Brien provides an account of how colonial narratives have relegated Indigenous peoples to the past as well as an analysis of what function those narratives have in colonialism. See Jean O'Brien, Firsting and Lasting: Writing Indians Out of Existence in New England (Minneapolis: University of Minnesota Press, 2010). I also note that John Borrows has strongly emphasized throughout his work that Indigenous laws, like all laws, are living laws that are not static. See generally Borrows, Indigenous Constitution, supra note 17.

42 Aaron Mills also has an excellent paper exploring the same metaphor in greater detail in relation to the nature of Indigenous law. See Aaron Mills, "Rooted Constitutionalism: Growing Political Community" in Michael Asch, John Borrows \& James Tully, eds, Resurgence and Reconciliation (Toronto: University of Toronto Press) [forthcoming]. 
choice, struggle, and contestation) held on to them over the generations. These stories remain an aspect of what has (and continues to) bind the WSÁNEĆ as a political, cultural, and legal community.

Cedar tried to continue his explanation. He explained to Raven that all of this does not mean that these stories have come through in some pristine state. Even if that were possible, Cedar explained that is not how stories work. Stories change depending on the context. They may be told in different ways, and they mean different things to different people. There is a great diversity to stories. There is not only one way to tell, interpret, or use a story. ${ }^{43}$ Stories are dynamic because they are about, and are a product of, dynamic and complex relationships in the world. Stories are therefore a vehicle for thinking, acting, and relating, Cedar explained. Each person grows and takes from these stories in different ways. In this light, Cedar did not see an emphasis on WSÁNEĆ stories as restrictive at all. In fact, the diversity of ways to interpret and use stories excited Cedar. That is what he wanted. That is what he thought stories were meant to do. He wanted them to be a framework for discussion and to give reason to think and act in new directions. ${ }^{44}$ Cedar wanted to give Raven an example; he thought it might help.

In WSÁNEĆ culture, one of the main stories about deer involves SMÍEF planning to kill the Creator, XÁLS. SMÍEF was one of the first men, and he had heard about XÁLS moving through WSÁNEĆ territory and changing some of the WSÁNEĆ people into animals. SMÍEF didn't want to become an animal so he planned to kill XÁLS. XÁLS discovered this intention, and eventually SMÍEF was turned into the deer that will be hunted by the WSÁNEĆ people for food and clothing. Cedar explained that one potential line of interpretation for this story involves an element of punishment. ${ }^{45}$ There were many elements of the story Cedar left out, but what he wanted to emphasize is that it does not create the imperative to understand and relate to deer in one way. ${ }^{46} \mathrm{In}$ fact, Cedar reminded Raven that he told a very different story and way of relating to SMÍEF while he was at Camosun College. There are other stories of SMÍEF in other contexts as well. What Cedar wanted to remind Raven was that WSÁNEĆ stories are not simple but are complex and dynamic.

Cedar wasn't sure that Raven and he would agree, but he hoped he had found the words to make his thoughts understandable to Raven. He didn't doubt the conversation would continue for quite some time, in many forms, in various contexts, and between many different people. There seemed to be a real tension here. For now, Cedar had done the best he could.

43 Borrows, Recovering Canada, supra note 6 at 14, identifies that Indigenous legal orders do "not depend on finding an 'authentic' first telling of [a story], uncorrupted by subsequent developments. In fact, the reinterpretation of tradition to meet contemporary needs is a strength of this methodology."

44 Val Napoleon and Hadley Friedland have worked with stories as a framework for discussing Indigenous law. See generally Val Napoleon \& Hadley Friedland, "An Inside Job: Engaging with Indigenous Legal Traditions through Stories" (2016) 61:4 McGill LJ 725.

45 While deer are hunted for food and clothing by the WSÁNEĆ, the deer is also blessed with a strong mind and ability to survive in the forest and hills.

46 In fact, I know another teaching about deer that says deer should not be referred to by the name SMÍEF while hunting. Rather, deer should be addressed as INES (grandchild) before and during the hunt as its life should not be taken for granted. Also, to use the name SMÍE‡ while hunting may cause one to focus too specifically on SMÍEF'S intention to kill or harm the Creator, XÁLS. Approaching the hunt in this unprepared manner may cause the intentions of SMÍE‡ to overwhelm the hunter, resulting in the hunter becoming lost, to be involved in a hunting accident, or some other harmful event. 
When Cedar awoke he did not feel particularly rested. Often Cedar's best insights would come to him in a dream. He would awake with a sense of clarity and a feeling of rejuvenation. He did not have that feeling on this occasion. His conversation with Raven had been tiring. He had lost a little confidence. Was his thinking promoting some type of harmful power dynamic? Was he misguided in some way? He had been looking through many books and theories that might contain new approaches to answer questions such as those Raven had. He thought it was important to have the answers, and he knew that theory could help. But the search could lead you astray, or so it felt at times. But perhaps this was also connected to a more general feeling of uncertainty and disconnection that had been growing in him as of late.

Cedar's time in Toronto was soon coming to an end. He had mixed feelings about this. His experience in Toronto had been great, and so too was the support he had from those at his school. He had made the right choice in coming to Toronto, and he had been learning a great deal. Not just regarding his studies but about himself as well. He would miss much about the school and the city. But Cedar had also begun to feel a disconnection. He wasn't himself. The feeling was growing. He felt captured by it. It weighed on him, and he was starting to become concerned. Perhaps he was feeling the pressure of finishing everything he needed to before he left. Cedar always placed a great deal of pressure on himself. It was something he was working on. It was not healthy, and it was draining on him. At home, he could sit and gaze upon the ocean, and perhaps at ŁEL,TOS. He could bathe in the ocean, an important WSÁNEĆ ceremony and teaching. He always felt rejuvenated after bathing. Climbing a mountain was also a great way to alleviate these feelings. He could see the sacred mountain of the WSÁNEĆ from his home. Each of these actions would make him think of his grandfather, his family, and all that was important to him. Toronto had many things to offer, but it did not have these. Well, he had a canning jar on his coffee table that contained a few rocks from the beach and water from the ocean in WSÁNEĆ territory, but that wasn't quite the same.

Cedar knew that he felt best about his work when he could take what he was learning in books, but not lose touch with the things that mattered most to him. He gained confidence when he could find this grounding. For most of the year Cedar had been contemplating a paper for a Law.Art.Culture. class he was taking. Originally, his ideas had been very theory driven. But as time passed, and his thoughts simmered, he saw it as an opportunity. He had the freedom to write not only about Indigenous law, and WSÁNEĆ stories, but to do so in any way he wanted. He felt it was an opportunity to regain some of the connection that had been slipping away from him. Cedar settled on writing a narrative. He thought that a story could help. He was not sure the shape it would take even as he wrote, but he felt excited about the possibilities it could create.

As Cedar wrote, many of his own thoughts, struggles, and ideas came to the fore. It became a type of selfreflection. It proved more difficult than he originally thought. The paper had been coming along slowly, and he had much left to write. He had started off by writing a fair amount about his grandfather. Cedar had just written about his friend SMÍEF in the field of Camosun College and about his grandfather's passing. It was a unique moment in his life that he would never forget. He wrote about the connection he felt. It was powerful. It could still be an emotional thing for him to write about. Cedar reflected upon how 
it can be difficult to capture a feeling in writing. Thinking and writing about SMÍEF on that day had helped him capture some of that connection he sought, though not all of it. But Cedar could only write so much in one day. Especially when it was personal. It was better to stop. The best realizations are never forced or over thought. Cedar knew this from experience. Ideas came to him more naturally at their own pace. They spoke the truest to him. He could feel them before he could describe them.

Cedar set aside his paper for the day. It was time to get outside. His office was small and had no windows. It was no way to spend a beautiful day. Spring had arrived in Toronto. It seemed to Cedar that was something to take advantage of. There was a pond behind the law school. While Cedar knew it was there, he never found reason or the opportunity to visit it the whole time he had been at the school. It was not the most beautiful pond he had seen, and the construction of the new building next to it was distracting. But to be honest, it was the most connected to nature he had felt in some time. Living in the city could be difficult that way at times.

While Cedar had taken a book with him to read on the politics of recognition and self-determination, he had allowed the story he had just written about SMÍEF to bring him to the pond, and before starting to read, he wanted to be sure to enjoy the surroundings. ${ }^{47} \mathrm{He}$ sat on a bench and enjoyed the sun and the peace it offered from everything else. Even better, as Cedar sat there, he made a new friend, the Goose. As Cedar sat there, Goose roamed around the bench eating grass. Goose came right up to his feet, eating the grass around his shoes. At its closest, Goose was literally inches away. Neither Cedar nor Goose interrupted the other. Goose continued to eat grass, and Cedar sat there and enjoyed the visit. Both shared the space together in this way for twenty-five to thirty minutes. Cedar had never had a Goose eat and visit so closely to him before. The experience and the timing of it were striking to Cedar.

Cedar could not say why, but he had never shared the story about SMÍEF at Camosun College and its connection to his grandfather's passing in any detail with anyone before. Cedar contemplated it on many occasions but kept it between himself and SMÍEF. What struck Cedar was that immediately after writing about SMÍEF for the first time, in the midst of the struggles he had been feeling, Goose visited him in a similar way. It was a unique experience, but just like with SMÍEF, it felt right. Of course, the whole thing could be considered a coincidence. But for Cedar it had more meaning. He had been struggling. Losing himself. The story of his grandfather and SMÍEF brought him to the pond. At the pond, his friend Goose reminded him of the importance of that story, and of much more. It helped him when he needed it.

Earlier, Cedar had talked at length with Raven. But that couldn't really capture all that he hoped. For Cedar, sitting there with Goose captured much more. He listened and felt something that gave him confidence, despite the concerns raised by Raven. He knew that it was possible to find insights in books that could help respond to the concerns raised by Raven. But Goose reminded him that they could be found elsewhere as well. Cedar found a great deal in the connections he had with SMÍEF, Goose, ŁEL,TOS, and in other places and stories. It is not that a story holds all the answers. What you do with those stories is just as important. That is what mattered to Cedar.

47 Avigail Eisenberg et al, eds, Recognition versus Self-Determination: Dilemmas of Emancipatory Politics (Vancouver: UBC Press, 2014). 
Cedar sat in front of his computer. He had found it difficult to know where to start the story for his paper. As he wrote, he didn't know the structure it would take. For the most part, he just started writing. He hoped that would work. But, just as he struggled in knowing where to start the paper, so too did he struggle knowing how to finish it. He knew there was always more to say and more to learn. He reflected on the story thus far and on the thoughts and words he had written. We have come full circle, Cedar realizes. That seemed appropriate to him. He knew how the story should end.

I have never forgotten the words that my father spoke to me one day when we were fishing here. He said that the river is a living thing and if you listen, he will speak to you. ${ }^{48}$

48 Clifford, supra note 1. 